\title{
Pengaruh Rasio Tinggi Blok Tegangan Tekan Dan Tinggi Efektif Terhadap Lentur Balok Bertulangan Tunggal
}

\author{
Agus Sugianto $^{1 *}$, Andi Marini Indriani ${ }^{2}$ \\ ${ }^{1,2}$ Dosen Program Studi Teknik Sipil dan Perencanaan Universitas Balikpapan \\ *agus.fadhil@yahoo.co.id
}

\begin{abstract}
One of the structural elements contained in buildings whose function is load bearing beam bending. Load supported include live load, load plate, heavy walls and his own heavy beams. Detained horizontal load is the force created by the earthquake and wind loads. Beams according to layout and function consisting of beam and joist. The goal in research was to determine the effect of the ratio of a (high block compressive stress) and $d$ (effective height of the beam) to beam bending and acquiring dimensional concrete beam reinforcement single-section more effectively to the flexural strength and deformation of the ratio a (high beam compressive stress)/d (effective height of the beam).

With the purposes of research to determine the effect of the ratio a/d beam to bending by type of beam collapse in accordance with SNI 2847-2002, then the model of the test object consists of a block of concrete the size $70 \times 150 \times 1200 \mathrm{~mm}$. 3 specimen, concrete blocks the size $70 \times 150 \times 1400 \mathrm{~mm}$. 3 specimen, concrete blocks the size 70x150x1600 mm. 3 specimen. The test results are analyzed to Vertical Load, Moment and Deformation.

The influence of the ratio a/d to the reinforcement of concrete beam flexural strength of a single load $(P)$, Moment $(M)$ if the deformation is getting smaller, the greater the deflection. The greater the ratio a/d will make concrete beam flexural strength diminishing, it is seen from the average value of deformation decreases, so all the most optimal specimen is a model specimen BL.MM.1. The influence of the ratio $a / d$ to the amount of deformation of the specimen visible BL.MM.1 with BL.MM.2, with the addition of the ratio a/d at 2:38 mm specimen is deformed by 0.038 mm. BL.MM.3 BL.MM.1 models with the addition of the ratio a/d of $4.76 \mathrm{~mm}$ specimen is deformed by $0.040 \mathrm{~mm}$.
\end{abstract}

Keywords: block the compressive stress, concrete beam, ratio a/d

\begin{abstract}
Abstrak
Salah satu elemen struktur yang terdapat dalam bangunan adalah balok yang fungsinya menahan beban lentur. Beban yang didukung meliputi beban hidup, beban plat, berat tembok dan berat sendiri balok. Beban horisontal yang ditahan adalah gaya yang ditimbulkan oleh beban gempa dan angin. Balok menurut letak dan fungsinya terdiri dari balok induk dan balok anak. Tujuan yang ingin dicapai pada penelitian ini adalah untuk mengetahui pengaruh rasio a (tinggi blok tegangan tekan) dan d (tinggi efektif balok) terhadap lentur balok dan memperoleh dimensi balok beton tulangan tunggal dengan penampang yang lebih efektif terhadap kuat lentur serta nilai deformasi terhadap rasio a (tinggi balok tegangan tekan)/d (tinggi efektif balok).

Sesuai tujuan penelitian untuk mengetahui pengaruh rasio a/d balok terhadap lentur berdasarkan jenis keruntuhan balok sesuai dengan SNI 2847-2002, maka model benda uji terdiri dari balok beton dengan ukuran 70x150x1200 mm. 3 benda uji, balok beton dengan ukuran 70x150x1400 mm. 3 benda uji, balok beton dengan ukuran 70x150x1600 mm. 3 benda uji. Hasil pengujian tersebut dianalisa terhadap Beban Vertikal, Momen dan Deformasi.

Pengaruh dari besarnya rasio a/d terhadap kuat lentur balok beton tulangan tunggal dengan beban (P), Momen (M) jika deformasi yang terjadi semakin kecil maka defleksi semakin besar. Semakin besar rasio a/d akan membuat kuat lentur balok beton semakin berkurang, hal ini terlihat dari nilai rata-rata deformasi yang semakin menurun, sehingga dari semua benda uji yang paling optimal adalah model benda uji BL.MM.1. Pengaruh dari rasio a/d terhadap besarnya deformasi terlihat dari benda uji BL.MM.1 dengan BL.MM.2, dengan penambahan rasio a/d sebesar $2.38 \mathrm{~mm}$ benda uji mengalami deformasi sebesar $0.038 \mathrm{~mm}$. Model BL.MM.1 dengan BL.MM.3 penambahan rasio a/d sebesar $4.76 \mathrm{~mm}$ benda uji mengalami deformasi sebesar $0.040 \mathrm{~mm}$.
\end{abstract}

Kata kunci: blok tegangan tekan, balok beton, rasio a/d 


\section{Pendahuluan}

\subsection{Latar Belakang}

Salah satu elemen struktur yang terdapat dalam bangunan adalah balok. Balok merupakan elemen struktur yang fungsinya menahan beban lentur. Beban vertikal yang didukung meliputi beban hidup, beban plat, berat tembok dan berat sendiri balok. Beban horizontal yang ditahan adalah gaya yang ditimbulkan oleh beban gempa dan angin. Balok menurut letaknya dan fungsinya terdiri dari balok induk dan anak.

Beton adalah material konstruksi yang sering digunakan dalam berbagai macam proyek konstruksi khususnya di Indonesia. Hal ini dikarenakan beton mudah dibuat baik di pabrik (precast) maupun langsung di tempat proyek berlangsung dan kekuatannya dapat diatur sedemikian rupa, sehingga sesuai dengan yang diinginkan, bahkan bentuk dan ukurannya dapat diatur sesuai kebutuhan. Beton memiliki kuat tekan yang cukup besar, akan tetapi kuat tariknya lebih kecil dari pada kuat tekannya, untuk itu, dibutuhkan tulangan untuk menahan gaya tarik yang terjadi pada beton terutama pada elemen balok.

Perhitungan balok beton bertulang pada penampang lentur dapat dibedakan menjadi dua, yaitu penampang bertulang tunggal dan penampang bertulang rangkap. Bila pada penampang balok beton hanya terdapat tulangan tarik saja, maka disebut penampang bertulang tunggal dan bila pada penampang balok beton terdapat tulangan tarik dan tulangan tekan, maka disebut penampang bertulang rangkap.

Tulangan tekan menurut Salmon(1993), tulangan tekan (tulangan rangkap) diperlukan bila rasio tulangan tarik maksimum untuk tulangan tunggal tidak mencukupi. Tetapi bila rasio tulangan tarik maksimum tulangan tunggal sudah mencukupi, tidak diperlukan tulangan tekan (tulangan rangkap) karena dianggap kurang ekonomis, karena peningkatan kuat lentur tidak sebanding dengan penambahan tulangan tekannya. Maksudnya sepanjang penampang direncanakan sebagai tulangan tunggal sudah mencukupi, maka tidak diperlukan tulangan tekan untuk menahan momen lentur, tetapi demikian, tulangan tekan harus tetap dipasang untuk tujuan lain, misalnya menahan sengkang. Oleh sebab itu, sebaiknya tindakan menambah tulangan tekan dengan tujuan meningkatkan kuat lentur dihindari, kecuali dalam keadaan terpaksa. Pengaruh peningkatan tulangan tekan terhadap kekuatan lentur umumnya $3 \%$ sampai $4 \%$, sehingga pengaruhnya dapat diabaikan. Besaran tulangan tekan dapat diambil sembarang, misalnya 0,2 kali tulangan tariknya.

Penelitian yang akan ditempuh yaitu dengan membandingkan tinggi efektif balok dengan panjang blok tegangan tekan yang berbeda. Dengan harapan untuk mendapatkan kekuatan lentur maksimal, sehingga dengan panjang berbeda diharapkan dapat lebih hemat.

Permasalahan desain penampang persegi beton terhadap beban lentur dengan tulangan tunggal (tanpa tulangan tekan) adalah menentukan luas tulangan yang diperlukan As dengan terlebih dahulu mengetahui unsur-unsur penampang beton yang terdiri dari ; ukuran penampang dengan lebar (b), tinggi efektif (d), momen ultimit $(\mathrm{Mu})$, mutu beton $\left(f_{\mathrm{c}^{\prime}}\right)$, dan mutu baja tulangan $\left(f_{\mathrm{y}}\right)$

\subsection{Rumusan masalah}

Rumusan masalah pada penelitian ini:

a. Berapa besar pengaruh variasi rasio a/d terhadap kuat lentur balok beton tulangan tunggal.

b. Berapa besar kuat lentur optimal yang dapat dipikul dari rasio a/d dimensi balok tulangan tunggal.

c. Berapa besar pengaruh rasio a/d terhadap besarnya deformasi yang terjadi.

\subsection{Tujuan penelitian}

Tujuan yang ingin dicapai adalah:

1. Untuk mengetahui pengaruh rasio a (tinggi balok tegangan tekan) dan tinggi efektif balok (d) terhadap lentur balok tulangan tunggal.

2. Memperoleh dimensi balok beton tulangan tunggal dengan penampang yang lebih efektif terhadap kuat lentur.

3. Memperoleh nilai deformasi terhadap rasio a (tinggi balok tegangan tekan) dan tinggi efektif balok (d). 


\subsection{Batasan masalah}

Batasan masalah :

a. Mutu Beton yang digunakan adalah $f_{\mathrm{c}}$, $23.79 \mathrm{MPa}$ dan mutu baja $f_{\mathrm{y}} 240 \mathrm{MPa}$

b. Tulangan pokok menggunakan baja D10 dan sengkang menggunakan tulangan baja D-8.

c. Pengujian yang dilakukan adalah pengujan kuat lentur balok dengan pembebanan statis bertahap.

\section{Metodologi Penelitian}

Metodologi yang akan dilaksanakan dalam penelitian ini adalah:

\subsection{Prosedur Pelaksanaan Penelitian}

Prosedur pelaksanaan penelitian seperti ditunjukkan dalam Gambar 1.

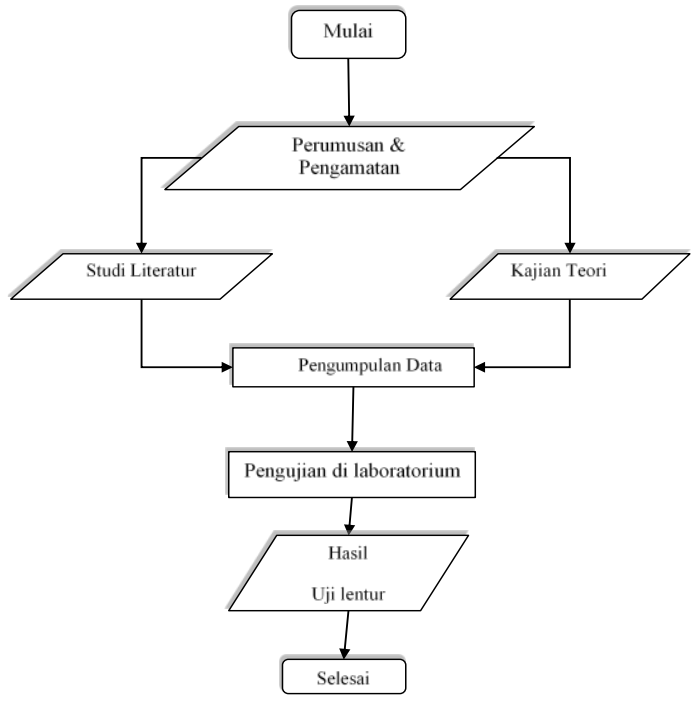

Gambar 3. Diagram pelaksanaan Penelitian

\subsection{Perhitungan Dimensi Benda Uji}

Sesuai dengan tujuan penelitian yaitu untuk meneliti pengaruh rasio panjang balok tegangan tekan dan tinggi efektif balok terhadap lentur balok berdasarkan kategori keruntuhan balok (Struktur Beton Lanjut, Geser balok modul 9, Agus Sugianto), Keruntuhan balok di bagi dalam 4 jenis:

a. Jenis I: Jika a/d <1/2, maka balok tinggi. Tegangan geser lebih menentukan daripada tegangan lentur

b. Jenis II: Jika $1<\mathrm{a} / \mathrm{d}<2 \frac{1}{2} 2$, maka balok pendek. Kekuatan gesernya melampaui kapasitas keretakan miring. c. Jenis III: Jika $2 \frac{1}{2}<<$ a/d $<6$ maka balok pendek. Kekuatan gesernya sama dengan kapasitas keretakan miring dan lentur mulai bersifat dominan.

d. Jenis IV: Jika a/d > 6 maka balok panjang. Keruntuhan yang terjadi adalah keruntuhan lentur

\subsection{Bahan dan Benda Uji}

\section{a. Bahan}

Bahan-bahan yang digunakan dalam pembuatan benda uji penelitian ini adalah :

1. Ready mix dengan mutu beton $\mathrm{K}_{300}$ atau setara dengan 23.79 MPa.

2. Tulangan Baja untuk tulangan pokok diameter $10 \mathrm{~mm}$ dan untuk sengkang menggunakan tulangan baja diameter 8 .

3. Kawat bendrat digunakan untuk merangkai tulangan-tulangan baja.

4. Kayu lapis digunakan untu membuat bekisting

b. Benda Uji

Benda uji terdiri dari

1. Balok beton dengan ukuran $70 \times 150 \times$ 1200 mm sebanyak 3 benda uji.

2. Balok beton dengan ukuran $70 \times 150 \times$ $1400 \mathrm{~mm}$ sebanyak 3 benda uji.

3. Balok beton dengan ukuran $70 \times 150 \times$ $1600 \mathrm{~mm}$ sebanyak 3 benda uji

\subsection{Proses Pengujian Kuat Lentur}

Pengujian kuat lentur dilakukan setelah beton mencapai umur 28 hari. Pelaksanaan pengujian kuat lentur balok dilakukan dengan cara :

1. Benda uji diletakkan pada alat uji tekan kekuatan maksimum 30 ton perletakan sendi dan rol.

2. Setelah siap dilakukan pengujian. Gaya/beban konstan diberikan secara perlahan-lahan dan dinaikkan secara berangsur-angsur hingga pada batas tertentu sampai pada tegangan maksimum, hingga benda uji mengalami retak, lendutan maksimum dan patah.

3. Retak yang terjadi ditandai pada benda uji saat pengujian, sehingga retakan yang terjadi dapat terekam dengan baik. Lendutan dan beban dicatat agar bisa diperoleh hubungan dengan retakan yang terjadi.

Variabel-variabel yang diukur dalam proses pengujian: 
- Beban (P). Pemberian beban pada pengujian dari beban awal hingga beban maksimum.

- Lendutan (deflection), $\delta$. Lendutan didapat dengan pencatatan pembacaan tiga buah dial pada masing-masing jenjang pemberian beban dari setiap titik-titik tinjau yang sudah ditentukan.

- Momen diperoleh dengan perhitungan. $M=1.6 P L+1.2 \mathrm{QL}$

Dimana :

$$
\begin{array}{ll}
\mathrm{M} & =\text { Momen }(\mathrm{kN}) \\
\mathrm{P} & =\operatorname{Beban}(\mathrm{kN}) \\
\mathrm{L} & =\text { Panjang bentang }(\mathrm{m})
\end{array}
$$

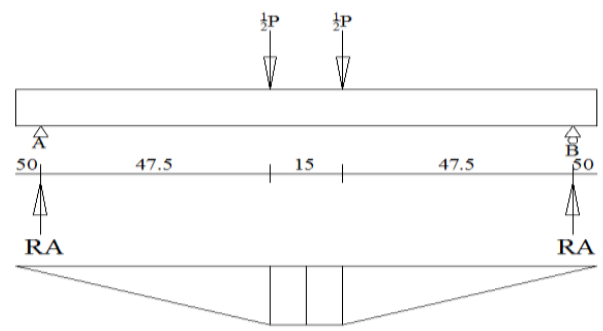

Sumber : Dipohusodo (1996),Struktur Beton Bertulang

Gambar 1. Momen pada tampang memanjang balok

\section{Hasil dan Pembahasan}

\subsection{Bentuk penampang}

Berikut adalah bentuk dan dimensi penampang yang digunakan sebagai pengujian kuat lentur.

\begin{tabular}{|c|c|c|c|c|c|c|c|c|}
\hline \multirow{3}{*}{$\mathrm{N}_{0}$} & \multirow{3}{*}{ Kode Balok } & \multirow{2}{*}{$f \mathrm{c}^{\prime}$} & \multirow{2}{*}{$f y^{\prime}$} & \multicolumn{3}{|c|}{ Dimensi Balok } & \multirow{2}{*}{ a } & \multirow{2}{*}{$\mathrm{L}$} \\
\hline & & & & $\mathrm{b}$ & $d$ & $\mathrm{~h}$ & & \\
\hline & & Мpa & Мра & $(\mathrm{mm})$ & (mm) & $(\mathrm{mm})$ & $(\mathrm{mm})$ & $(\mathrm{mm})$ \\
\hline 1 & BL.MM $1 \mathrm{~A}$ & 23.79 & 240 & 150 & 42 & 70 & 475 & 1200 \\
\hline 2 & BL.MM IB & 23.79 & 240 & 150 & 42 & 70 & 475 & 1200 \\
\hline 3 & BL.MM IC & 23.79 & 240 & 150 & 42 & 70 & 475 & 1200 \\
\hline 4 & BL.MM 2A & 23.79 & 240 & 150 & 42 & 70 & 575 & 1400 \\
\hline 5 & BL.MM $2 B$ & 23.79 & 240 & 150 & 42 & 70 & 575 & 1400 \\
\hline 6 & BL.MM2C & 23.79 & 240 & 150 & 42 & 70 & 575 & 1400 \\
\hline 7 & BL.MM 3A & 23.79 & 240 & 150 & 42 & 70 & 675 & 1600 \\
\hline 8 & BL.MM 3B & 23.79 & 240 & 150 & 42 & 70 & 675 & 1600 \\
\hline 9 & BL.MM 3C & 23.79 & 240 & 150 & 42 & 70 & 675 & 1600 \\
\hline
\end{tabular}

Tabel 1. Dimensi penampang benda uji

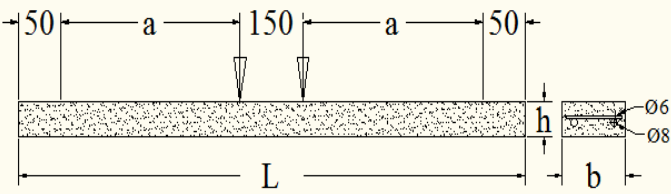

Sumber : Hasil Uji Laboratorium, Teknik Sipil

Universitas Balikpapan
Keterangan :

$\mathrm{BL}=$ Benda uji model balok lentur

$\mathrm{MM}=$ Inisial penguji

$1 \mathrm{~s} / \mathrm{d} 3=$ Nomor jenis variasi benda uji

$\mathrm{A}, \mathrm{B}, \mathrm{C}=$ jumlah variasi tiap jenis benda uji

3.2. Tahapan pelaksanaan pengujian

Alat uji kuat lentur diletakkan pada area yang median yang rata dan waterpass dibantu dengan empat balok penyangga setting manometer sehingga mudah di baca pada saat pengujian, letakkan benda uji pada alat kuat lentur kemudian pasang 3 buah manometer, 2 buah pada sisi bagian atas dan 1 pada bagian samping. Penempatan kamera pada posisi yang sudah ditentukan sebelumnya dan siap untuk merekam, setelah semua sudah terpasang dengan baik barulah dimulai untuk pengujian.

\subsection{Hasil pengujian kuat lentur beton dengan variasi panjang}

Hasil yang diperoleh antara lain: hubungan antara kekuatan benda uji dengan beban (P), hubungan antara kekuatan benda uji dengan momen $(\mathrm{M})$, hubungan antara kekuatan benda uji dengan defleksi $(\delta)$, dan hubungan kekuatan benda uji dengan deformasi.

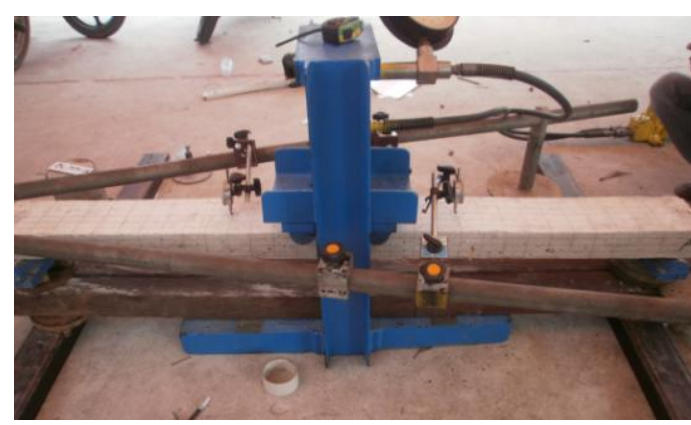

Gambar 2. Pengujian Kuat Lentur

Dari Gambar 2 pengujian kuat lentur, sehingga diperoleh data hasil pengujian laboratorium sebagai berikut: 
Tabel 2. Hasil Pengujian Laboratorium

\begin{tabular}{|c|c|c|c|c|c|c|c|c|c|c|c|c|c|c|c|}
\hline \multirow{3}{*}{ No } & \multirow{3}{*}{ Kode Balok } & \multirow{3}{*}{$f c^{\prime}$} & \multirow{2}{*}{$f y^{\prime}$} & \multicolumn{4}{|c|}{ Dimensi Balok } & \multirow{2}{*}{\multicolumn{2}{|c|}{\begin{tabular}{|l} 
Penulangan \\
ul. Tarn seng
\end{tabular}}} & \multicolumn{3}{|c|}{ Dial Manometer } & & \multirow{3}{*}{\begin{tabular}{|l} 
\\
$(\mathrm{mm})$ \\
\end{tabular}} & \multirow{3}{*}{\begin{tabular}{|c|} 
Bebar \\
Pu \\
a) (Ton) \\
\end{tabular}} \\
\hline & & & & b & d & $d^{\prime}$ & h & & & 1 & 2 & 3 & & & \\
\hline & & & Мpa & $\mathrm{mm}$ & $\mathrm{mm}$ & $\mathrm{mm}$ & $\mathrm{mm}$ & $\mathrm{mm}$ & $\mathrm{mm}$ & (mm) & (mm) & (mm) & & & \\
\hline 1 & BL.MM 1A & 26.73 & 240 & 150 & 42 & 28 & 70 & $\emptyset 10$ & 98 & 23.90 & 23.3 & 3.5 & 1200 & 475 & 3.00 \\
\hline 2 & BL.MM IB & 26.73 & 240 & 150 & 42 & 28 & 70 & $\emptyset 10$ & 98 & 14.30 & 12.7 & 5.7 & 1200 & 475 & 2.75 \\
\hline 3 & BL.MM IC & 26.73 & 240 & 150 & 42 & 28 & 70 & $\emptyset 10$ & 98 & 14.10 & 13.2 & 5 & 1200 & 475 & 3.00 \\
\hline 4 & BL.MM $2 A$ & 26.73 & 240 & 150 & 42 & 28 & 70 & $\emptyset 10$ & 98 & 28.40 & 29 & 3.1 & 1400 & 575 & 1.50 \\
\hline 5 & BL.MM $2 B$ & 26.73 & 240 & 150 & 42 & 28 & 70 & $\emptyset 10$ & 98 & 18.60 & 19.9 & 1.37 & 1400 & 575 & 250 \\
\hline 6 & BL.MM $2 C$ & 26.73 & 240 & 150 & 42 & 28 & 70 & $\emptyset 10$ & 98 & 37.15 & 38.5 & 1.7 & 1400 & 575 & 1.75 \\
\hline 7 & BL.MM $3 A$ & 26.73 & 240 & 150 & 42 & 28 & 70 & $\emptyset 10$ & 98 & 13.30 & 22.1 & 2.04 & 1600 & 675 & 2.25 \\
\hline 8 & BL.MM 3B & 26.73 & 240 & 150 & 42 & 28 & 70 & $\emptyset 10$ & 98 & 27.40 & 33 & 2.43 & 1600 & 675 & 2.25 \\
\hline 9 & BL.MM 3 C & 26.73 & 240 & 150 & 42 & 28 & 70 & $\phi 10$ & 98 & 19.30 & 23.5 & 1.3 & 1600 & 675 & 250 \\
\hline
\end{tabular}

Sumber : Hasil Uji Laboratorium, Teknik Sipil Universitas Balikpapan

\subsection{Hubungan rasio panjang tegangan tekan dan tinggi efektif dengan beban}

Hasil pengujian laboratorium untuk pengaruh rasio panjang blok tegangan tekan dan tinggi efektif balok beton tulangan tunggal terhadap 'beban (P) pada model benda uji, yang dapat dilihat pada tabel dibawah ini.

Tabel 3. Hubungan rasio a/d dengan beban $(P)$

\begin{tabular}{|c|c|c|c|c|c|c|c|}
\hline & \multirow{3}{*}{ Kode } & \multicolumn{3}{|c|}{ Dimensi } & \multirow[t]{2}{*}{ Rasio } & \multirow{2}{*}{$\begin{array}{l}\text { Beban } \\
\text { Aktual }\end{array}$} & \multirow{2}{*}{$\begin{array}{l}\text { Bebant } \\
\text { Analisa }\end{array}$} \\
\hline $\mathrm{No}$ & & L & a & $d$ & & & \\
\hline & & $(\mathrm{mm})$ & $(\mathrm{mm})$ & (mm) & $(\mathrm{mm})$ & (kN) & \\
\hline 1 & BL.MM. 1 & 1200 & 475 & 42 & 11.31 & 2.92 & $2.9 \%$ \\
\hline 2 & BL.MM. 2 & 1400 & 575 & 42 & 13.69 & 2.50 & 2.) \\
\hline 3 & BL.MM. 3 & 1600 & 675 & 42 & 16.07 & 2.33 & 21 \\
\hline
\end{tabular}

Sumber: Hasil Uji Laboratorium, Teknik Sipil Universitas Balikpapan

Dari Tabel 3 hubungan benda uji terhadap beban, diperoleh data sehingga dapat diuraikan sebagai berikut:

a. Model balok BL.MM.1 pengaruh rasio panjang tegangan tekan dan tinggi efektif balok beton bertulangan tunggal terhadap beban dengan panjang blok tegangan tekan $475 \mathrm{~mm}$ dan tinggi efektif balok $42 \mathrm{~mm}$ atau dengan rasio $11.31 \mathrm{~mm}$ diperoleh nilai rata-rata beban aktual $2.92 \mathrm{kN}$.

b. Model balok BL.MM.2 pengaruh rasio panjang blok tegangan tekan dan tinggi efektif balok beton tulangan tunggal terhadap beban, ditambah panjang blok tegangan tekannya dengan rasio 13.69 $\mathrm{mm}$ menjadi $575 \mathrm{~mm}$ diperoleh nilai beban aktual $2.5 \mathrm{kN}$, sehingga benda uji mengalami penurunan kemampuan sebesar $13.54 \%$ dari beban aktual model BL.MM.1

c. Model balok BL.MM.3 pengaruh rasio panjang blok tegangan tekan dan tinggi efektif balok beton tulangan tunggal terhadap beban ditambah panjang blok tegangan tekannya menjadi $675 \mathrm{~mm}$ dengan rasio $16.07 \mathrm{~mm}$, diperoleh nilai beban aktual rata-rata $2.33 \mathrm{kN}$ turun $12.77 \%$ dari beban aktual model BL.MM. 2 dan $20.00 \%$ dari beban aktual model BL.MM.1

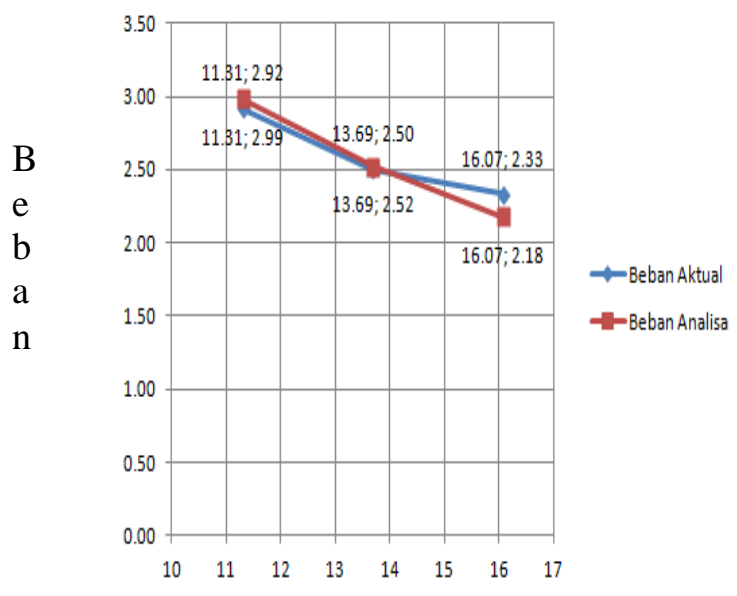

Rasio a/d

Gambar 3. Kurva hubungan a/d dengan beban

Dari Gambar 3 kurva hubungan rasio panjang tegangan tekan (a) dan tinggi efektif balok (d) terhadap beban dengan perbandingan untuk hubungan rasio panjang tegangan tekan (a) dan tinggi efektif balok (d) untuk model BL.MM. 1 : BL.MM. 2 : BL.MM.3 adalah $1: 1.21: 1.42$ diperoleh perbandingan nilai beban $=1: 0.86: 0.80$.

\subsection{Hubungan beban dengan defleksi}

Tabel 4. Analisa hasil pengujian laboratorium

\begin{tabular}{|c|c|c|c|c|c|c|c|}
\hline \multirow{3}{*}{ No } & \multirow{3}{*}{ Kode } & \multicolumn{3}{|c|}{ Dimensi } & \multirow{2}{*}{$\begin{array}{l}\text { Rasio } \\
\text { (ald })\end{array}$} & \multirow{2}{*}{$\begin{array}{c}\text { Defleksi } \\
\text { Aktual }\end{array}$} & \multirow{2}{*}{$\begin{array}{l}\text { Defteksi } \\
\text { Analisa }\end{array}$} \\
\hline & & L & $a$ & d & & & \\
\hline & & $(\mathrm{mm})$ & $(\mathrm{mm})$ & $(\mathrm{mm})$ & $(\mathrm{mm})$ & $(\mathrm{mm})$ & $(\mathrm{mm})$ \\
\hline 1 & "BL.MM. 1 & 1200 & 4775 & 42 & 11.31 & 46.11 & 477.20 \\
\hline 2 & BL.MM. 2 & 1400 & & 42 & 13.69 & 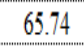 & 66.31 \\
\hline 3 & BL. MM. 3 & 1600 & 675 & 42 & 16.07 & 104.31 & 97.49 \\
\hline
\end{tabular}

Sumber : Hasil Uji Laboratorium, Teknik Sipil Universitas Balikpapan 
Berdasarkan Tabel 4 hasil pengujian di atas, kemudian diperoleh nilai beban yang dirata-ratakan untuk pengaruh rasio panjang tegangan tekan dan tinggi efektif balok beton tulangan tunggal terhadap Defleksi diperoleh:

a. Model balok BL.MM.1 dengan panjang blok tegangan tekan sebesar $475 \mathrm{~mm}$ dan tinggi efektif $42 \mathrm{~mm}$ atau dengan rasio $11.31 \mathrm{~mm}$ diperoleh nilai rata-rata beban aktual $2.92 \mathrm{kN}$ diperoleh nilai defleksi sebesar $46.11 \mathrm{~mm}$.

b. Pada model balok BL.MM.2 dengan rasio panjang blok tegangan tekan dan tinggi efektif balok sebesar $13.69 \mathrm{~mm}$ dan nilai rata-rata beban aktual $2.50 \mathrm{kN}$ diperoleh nilai defleksi sebesar 65.74 $\mathrm{mm}$, mengalami kenaikan sebesar 42.56\% dari model BL.MM.1

c. Pada model balok BL.MM.3 dengan panjang blok tegangan tekan sebesar 675 $\mathrm{mm}$, nilai beban aktual rata-rata $2.33 \mathrm{kN}$ diperoleh nilai defleksi sebesar 104.31 mm. naik 58.68\% dari model BL.MM.2 dan $126.22 \%$ dari model BL.MM.1

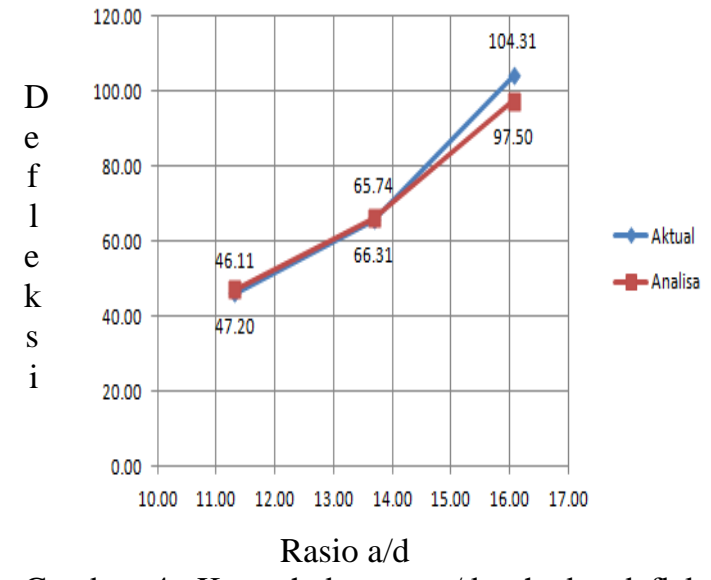

Gambar 4. Kurva hubungan a/d terhadap defleksi

Dari Gambar 4 kurva hubungan rasio panjang tegangan tekan (a) dan tinggi efektif balok (d) terhadap defleksi dengan perbandingan untuk hubungan rasio panjang tegangan tekan (a) dan tinggi efektif balok (d) untuk model BL.MM. 1 : BL.MM. 2 : BL.MM.3 adalah $1: 1.21: 1.42$ diperoleh perbandingan nilai defleksi $=1: 1.43: 2.26$.

\subsection{Hubungan rasio a/d dengan momen}

Hasil pengujian diperoleh momen disetiap perubahan panjang pada benda uji, yang dapat dilihat pada tabel dibawah ini.
Tabel 5. Hubungan rasio a/d dengan momen.

\begin{tabular}{|c|c|c|c|c|c|c|c|}
\hline \multirow{3}{*}{$\mathrm{N}$} & \multirow{3}{*}{ Kode } & \multicolumn{3}{|c|}{ Dimensi } & \multirow{2}{*}{$\begin{array}{l}\text { Rasio } \\
\text { (a/d) }\end{array}$} & \multirow{2}{*}{$\begin{array}{l}\text { Beban } \\
\text { Aktual }\end{array}$} & \multirow{2}{*}{ Momen } \\
\hline & & L & a & d & & & \\
\hline & & $(\mathrm{mm})$ & $(\mathrm{mm})$ & $(\mathrm{mm})$ & $(\mathrm{mm})$ & $(\mathrm{kN})$ & $(\mathrm{kNm})$ \\
\hline 1 & BL. MM. 1 & 1200 & 475 & 42 & 11.31 & 2.92 & 1.04 \\
\hline 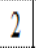 & BL. MM. 2 & 1400 & 575 & 42 & 13.69 & 2.50 & 0.87 \\
\hline 3 & BL. MM. 3 & 1600 & 675 & 42 & 16.07 & 2.33 & 0.75 \\
\hline
\end{tabular}

Sumber : Hasil Uji Laboratorium, Teknik Sipil Universitas Balikpapan

Dari Tabel 5 hubungan rasio a/d dengan momen dapat diuraikan sebagai berikut:

a. Model balok BL.MM.1 rasio $11.31 \mathrm{~mm}$ diperoleh nilai momen 1.04 kN.m dari perhitungan momen dengan beban aktual $2.92 \mathrm{kN}$.

b. Model balok BL.MM.2, rasio $11.31 \mathrm{~mm}$ diperoleh nilai momen $0.87 \mathrm{kN} . \mathrm{m}$ dari perhitungan momen dengan beban aktual $2.5 \mathrm{kN}$, menurun $15.84 \%$ dari model BL.MM.1.

c. Model balok BL.MM.3 rasio $11.31 \mathrm{~mm}$ diperoleh nilai momen 0.75 kN.m dari perhitungan momen beban aktual 2.33 $\mathrm{kN}$, menurun $13.09 \%$ dari model BL.MM.2 dan $27.54 \%$ dari model BL.MM.1.

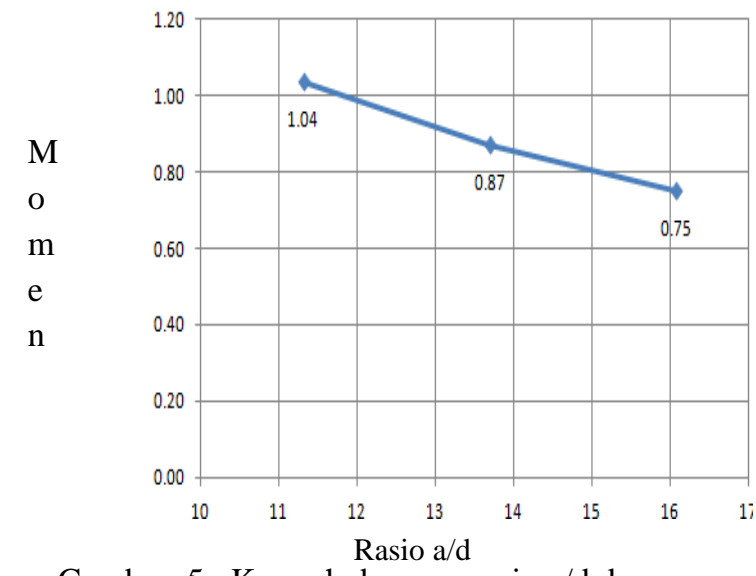

Gambar 5. Kurva hubungan rasio a/d dengan momen

Dari Gambar 5 kurva hubungan rasio panjang tegangan tekan (a) dan tinggi efektif balok (d) terhadap momen dengan perbandingan untuk hubungan rasio panjang tegangan tekan (a) dan tinggi efektif balok (d) untuk model BL.MM. 1 : BL.MM. 2 : 
BL.MM.3 adalah $1: 1.21: 1.42$ diperoleh perbandingan nilai defleksi $=1: 0.84: 0.72$.

\subsection{Hubungan benda uji dengan deformasi}

Hasil pengujian pengaruh rasio panjang tegangan tekan dan tinggi efektif terhadap kuat lentur balok beton tulangan tunggal diperoleh deformasi yang berbeda pada setiap perubahan panjang pada benda uji, yang dapat dilihat pada tabel dibawah ini.

Tabel 6. Hubungan rasio a/d terhadap deformasi

\begin{tabular}{|c|c|c|c|c|c|c|c|c|c|c|}
\hline & \multirow{3}{*}{ Kode Balok } & \multicolumn{2}{|c|}{ Dimensi } & \multirow{2}{*}{ L } & & \multirow{2}{*}{$\begin{array}{l}\text { Rasio } \\
\text { ald }\end{array}$} & \multicolumn{3}{|c|}{ Dial Manometer } & \multirow{2}{*}{$\begin{array}{c}\text { Deformasi } \\
3 \mathrm{~h}\end{array}$} \\
\hline & & d & $\mathrm{h}$ & & & & 1 & 2 & 3 & \\
\hline & & $\mathrm{mm}$ & $\mathrm{mm}$ & (mm) & (mm) & $(\mathrm{mm})$ & (mm) & $(\mathrm{mm})$ & (mm) & $(\mathrm{mm})$ \\
\hline 1 & BL.MM 1A & 42 & 70 & 1200 & 475 & $\mid 11.31$ & 23.90 & 23.3 & 3.5 & 0.050 \\
\hline 2 & BL.MM IB & 42 & 70 & 1200 & 475 & 11.31 & 14.30 & 12.7 & 5.7 & 0.081 \\
\hline 3 & BL.MMIC & 42 & 70 & 1200 & 475 & 11.31 & 14.10 & 13.2 & 1 & 0.071 \\
\hline 4 & BL.MM2A & 42 & 70 & 1400 & 575 & 13.69 & 28.40 & 29 & 3.1 & 0.044 \\
\hline 5 & BL.MM 2B & 42 & 70 & 1400 & 575 & 13.69 & 18.60 & 19.9 & 1.37 & 0.020 \\
\hline 6 & BL.MM2C & 42 & 70 & 1400 & 575 & 13.69 & 37.15 & 38.5 & 1.7 & 0.024 \\
\hline 7 & BLLMM 3A & 42 & 70 & 1600 & 675 & 16.07 & 13.30 & 22.1 & 2.04 & 0.029 \\
\hline 8 & BL.MM 3B & 42 & 70 & 1600 & 675 & 16.07 & 27.40 & 33 & 2.43 & 0.035 \\
\hline 9 & BL.MM 3C & 42 & 70 & 1600 & 675 & 16.07 & 19.30 & 23.5 & 1.3 & 0.019 \\
\hline
\end{tabular}

Sumber : Hasil Uji Laboratorium, Teknik Sipil Universitas Balikpapan

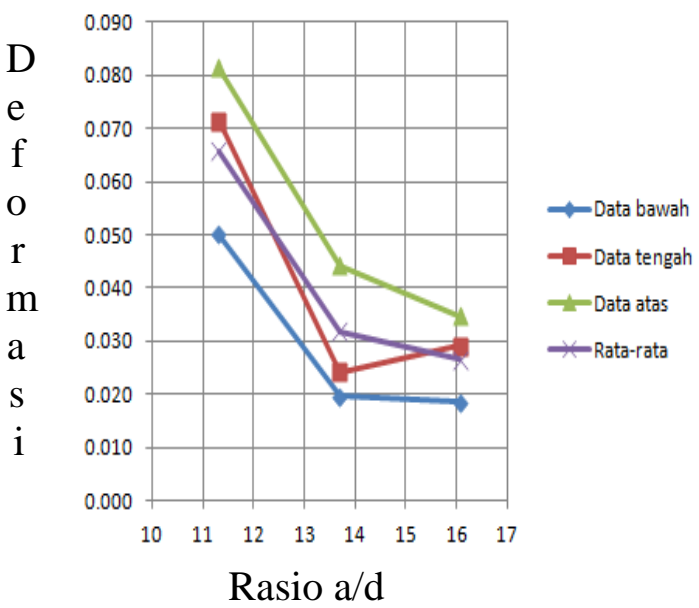

Gambar 6. Kurva hubungan rasio a/d dengan deformasi

Dari Gambar 6 hubungan rasio a/d terhadap deformasi dapat diuraikan sebagai berikut:

a. Data bawah yang terdiri dari model balok BL.MM.1A, 2B dan 3C diambil nilai deformasi terkecil dari masing masing model BL.MM 1, BL.MM.2 dan BL.MM.3. b. Data atas yang terdiri dari model balok BL.MM 1B, 2A dan 3B nilai deformasi terbesar dari masing-masing model BL.MM 1, BL.MM.2 dan BL.MM.3.

c. Data atas yang terdiri dari model balok BL.MM 1C, 2C dan 3A diambil nilai deformasi diantara terbesar dan terkecil dari masing-masing model BL.MM 1, BL.MM.2 dan BL.MM.3.

d. Data rata-rata merupakan nilai deformasi rata-rata dari masing-masing model BL.MM 1, BL.MM.2 dan BL.MM.3.

e. Dari kurva yang diambil dari data bawah, perbandingan untuk hubungan rasio panjang blok tegangan tekan (a) dan tinggi efektif balok (d) untuk model BL.MM.1A : BL.MM.2B : BL.MM.3C adalah $1: 1.21: 1.42$ diperoleh perbandingan nilai deformasi $=1: 0.39$ : 0.37 .

f. Dari kurva yang diambil dari data atas, perbandingan untuk hubungan rasio panjang blok tegangan tekan (a) dan tinggi efektif balok (d) untuk model BL.MM.1B : BL.MM.2A : BL.MM.3B adalah $1: 1.21: 1.42$ diperoleh perbandingan nilai deformasi $=1: 0.54$ : 0.43 .

g. Dari kurva yang diambil dari data tengah, perbandingan untuk hubungan rasio panjang blok tegangan tekan (a) dan tinggi efektif balok (d) untuk model BL.MM.1C : BL.MM.2C : BL.MM.3A adalah $1: 1.21: 1.42$ diperoleh perbandingan nilai deformasi $=1: 0.34$ : 0.41 .

h. Dari kurva yang diambil dari data ratarata, perbandingan untuk hubungan rasio panjang blok tegangan tekan (a) dan tinggi efektif balok (d) untuk model BL.MM.1 : BL.MM.2 : BL.MM.3 adalah $1: 1.21: 1.42$ diperoleh perbandingan nilai deformasi $=1: 0.49$ : 0.41 . 


\section{Analisa hasil pembahasan}

Tabel 7. Hasil Analisa Penelitian Aktual

\begin{tabular}{|c|c|c|c|c|c|c|c|c|c|}
\hline \multirow{3}{*}{$\mathrm{No}$} & \multirow{3}{*}{ Kode } & \multicolumn{3}{|c|}{ Dimensi } & \multirow{2}{*}{$\begin{array}{l}\text { Rasio } \\
\text { (ad) }\end{array}$} & \multirow{2}{*}{\begin{tabular}{|c} 
Beban \\
Pul \\
\end{tabular}} & \multirow{2}{*}{$\begin{array}{c}\text { Defleksi } \\
\Delta\end{array}$} & \multirow{2}{*}{$\begin{array}{c}\text { Momen } \\
\mathrm{M}\end{array}$} & \multirow{2}{*}{ Deformas } \\
\hline & & L & $a$ & $d$ & & & & & \\
\hline & & (mm) & (mm) & $(\mathrm{mm})$ & (mm) & $(\mathrm{kN})$ & $(\mathrm{kN})$ & $(\mathrm{kN})$ & (mm) \\
\hline 1 & BL.MM. 1 & 1200 & 475 & 42 & 11.31 & 2.92 & 46.11 & 1.04 & 0.066 \\
\hline${ }^{\prime}$ & BL.MM. 2 & 1400 & 575 & 42 & 13.69 & 250 & 65.74 & 0.87 & 0.032 \\
\hline 3 & BL.MM 3 & 1600 & 675 & 42 & 16.07 & 2.33 & 104.31 & 0.75 & 0.027 \\
\hline
\end{tabular}

Sumber : Hasil Uji Laboratorium, Teknik Sipil Universitas Balikpapan

Berdasarkan Tabel 4.5 hasil analisa penelitian dapat diuraikan mengenai pengaruh perbandingan panjang blok tegangan tekan dan tinggi efektif terhadap kuat lentur balok tulangan tunggal adalah:

a. Rasio $\mathrm{a} / \mathrm{d}=11.31 \mathrm{~mm}$ diperoleh nilai beban (P) rata-rata $2.92 \mathrm{kN}$., defleksi $(46.11 \mathrm{~mm})$, momen $(1.04 \mathrm{kNm})$ dan deformasi $(0.066 \mathrm{~mm})$.

b. Balok model BL.MM.2 rasio a/d = 13.69 $\mathrm{mm}$ diperoleh nilai beban $(\mathrm{P})=2.50 \mathrm{kN}$ dari model BL.MM.1, turun sebesar $14.29 \%$, defleksi sebesar $65.74 \mathrm{~mm}$ atau naik $42.56 \%$, momen turun sebesar $15.84 \%$ menjadi $0.87 \mathrm{kNm}$ dan deformasi turun $51.41 \%$ menjadi 0.032 $\mathrm{mm}$.

c. Balok model BL.MM.3 rasio a/d = 13.mm diperoleh nilai beban $(\mathrm{P})=2.33$ $\mathrm{kN}$ dari model BL.MM.1, turun sebesar $6.67 \%$, defleksi sebesar $104.31 \mathrm{~mm}$ atau naik $58.68 \%$, momen turun sebesar $13.90 \%$ menjadi $0.75 \mathrm{kNm}$ dan deformasi turun $16.55 \%$ menjadi 0.027 $\mathrm{mm}$.

\section{Kesimpulan}

1. Semakin besar rasio a/d balok beton tulangan tunggal terhadap beban $(\mathrm{P})$, Momen (M) maka deformasi yang terjadi semakin kecil sedang menjadi defleksi semakin besar.

2. Semakin besar rasio a/d akan menbuat kuat lentur balok beton semakin berkurang, hal ini terlihat dari nilai ratarata deformasi yang semakin menurun, sehingga dari semua benda uji yang paling optimal adalah model benda uji BL.MM.1
3. Pengaruh dari rasio a/d terhadap besarnya deformasi terlihat dari benda uji BL.MM.1 dengan BL.MM.2, dengan penambahan rasio a/d sebesar $2.38 \mathrm{~mm}$ benda uji mengalami deformasi sebesar $0.038 \mathrm{~mm}$. dan dari model BL.MM.1 dengan BL.MM.3 dengan penambahan rasio a/d sebesar $4.76 \mathrm{~mm}$ benda uji mengalami deformasi sebesar $0.040 \mathrm{~mm}$.

\section{Daftar Pustaka}

[1] Badan Standarisasi Nasional, SKSNI 03-2847-2002. Standar Tata Cara Perencanaan Struktur Beton Untuk Bangunan Gedung

[2] Direktorat Penyelidikan Masalah Bangunan Dirjen Cipta Karya Departeman Pekerjaan Umum Peraturan Beton Indonesia, 1971

[3] Dipohusodo (1996),Struktur Beton Bertulang

[4] Wang dan Salmon (1993). Disain Beton Bertulang. Diterjemahkan oleh Binsar Hariandja. 